\title{
The QT Interval in Patients with SARS-CoV-2 Infection Treated with Hydroxychloroquine/Azithromycin
}

Ehud Chorin MD PhD, Matthew Dai MD, Eric Shulman MD, Lalit Wadhwani MD, RoiBar-Cohen MD, Chirag Barbhaiya MD, Anthony Aizer MD, Douglas Holmes MD, Scott Bernstein MD, Michael Spinelli MD, David S. Park MD PhD, Larry A. Chinitz MD, Lior Jankelson MD PhD

${ }^{1}$ Lenon H. Charney Devision of Cardiology, Cardiac Electrophysiology, NYU Langone Health, New York University School of Medicine, NY, USA.

Total word count: 1251

Running title: Hydroxychloroquine/Azithromycin and QTc prolongation in SARS-CoV2 infection

Corresponding authors:

Lior Jankelson MD PhD and Ehud Chorin MD PhD

Conflicts of interest: None

Financial Disclosures: None

Key Words: Hydroxychloroquine, Azithromycin, QTc, Sudden Death, Torsades De Point 
medRxiv preprint doi: https://doi.org/10.1101/2020.04.02.20047050; this version posted April 3, 2020. The copyright holder for this preprint (which was not certified by peer review) is the author/funder, who has granted medRxiv a license to display the preprint in perpetuity.

All rights reserved. No reuse allowed without permission.

\section{Abstract}

We report the change in the QT interval in 84 adult patients with SARS-CoV-2 infection treated with Hydroxychloroquine/Azithromycin combination. QTC prolonged maximally from baseline between days 3 and 4 . in $30 \%$ of patients QTC increased by greater than $40 \mathrm{~ms}$. In $11 \%$ of patients QTc increased to $>500 \mathrm{~ms}$, representing high risk group for arrhythmia. The development of acute renal failure but not baseline QTC was a strong predictor of extreme QTc prolongation.

\section{Main}

The SARS-CoV-2 pandemic is resulting in a staggering worldwide morbidity and mortality currently estimated at more than 650,000 positive cases and more than 30,000 confirmed deaths as of March 28, 2020 [1]. Although there are no approved drugs to prevent or treat SARS-CoV-2 infection, a recent report suggested that the combination of Hydroxychloroquine with Azithromycin (HY/AZ) may have favorable effect on clinical outcomes and viral load of infected patients [2]. This, has resulted in massive adoption of the regimen by clinicians worldwide. However, both medications have been independently shown to increase the risk for QT interval prolongation, drug-induced torsades de pointes ( $T d P)$, and drug induced-sudden cardiac death $(S C D)$ [3-6]. There is no data regarding the effect of HY/AZ on the QT interval and the risk for malignant arrhythmia induction. Given the vast adoption of the regimen, including for post exposure prophylaxis [7], and the inherent risk for cardiac involvement in SARS-CoV-2 disease [8], we report here the change in QTC 
medRxiv preprint doi: https://doi.org/10.1101/2020.04.02.20047050; this version posted April 3, 2020. The copyright holder for this preprint (which was not certified by peer review) is the author/funder, who has granted medRxiv a license to display the preprint in perpetuity.

All rights reserved. No reuse allowed without permission.

interval and the risk for TdP in 84 consecutive patients admitted to our institution with SARS-CoV-2 infection and treated with $\mathrm{HY} / \mathrm{AZ}$.

The clinical and epidemiological characteristics are presented in Table 1. Four patients died from multi-organ failure, without evidence of arrhythmia. There were no TdP events recorded, including in patients with severely prolonged QTc, defined as greater than $500 \mathrm{~ms}$. The average time of ECG follow up post HY/AZ exposure was $4.3+/-1.7$ days. The QTc interval prolonged from a baselines of $435 \pm 24 \mathrm{~ms}$ to a maximal value of $463 \pm 32 \mathrm{~ms}(p<0.001)$ which occurred on day $3.6 \pm 1.6$ of therapy. The change in daily QTC interval is presented in Figure 1. Of note, $11 \%$ of patients developed new severe QTC prolongation of $>500 \mathrm{~ms}$. On multivariate analysis, the development of acute renal failure was a significant predictor of severe QTC prolongation. Baseline Creatinine and Coadministration of Amiodarone trended for significance, as opposed to other QT prolonging medications. Importantly, baseline QTC and QTC > 460 ms did not predict QTc prolongation (supplementary table 1). The effectiveness of Hydroxychloroquine in treating SARS-CoV-2 infection was demonstrated in several invitro studies $[9,10]$ and in one small human study $[2,11]$. However, given the lack of effective therapy, this combination is used liberally across the world and is recommended in multiple guidelines [12]. In this preliminary work we found that the in patients treated with HY/AZ QTC prolonged significantly. In $11 \%$ of patients, QTc prolonged to $>500 \mathrm{~ms}$, a known marker for high risk of malignant arrhythmia and sudden cardiac death [13-15]. Of note, recent guidance suggested screening of candidate patients for novel SARS-CoV-2 therapies, including $\mathrm{HY} / \mathrm{AZ}$ based on baseline QTC [16]. Our data suggest that baseline QTC is not a reliable 
medRxiv preprint doi: https://doi.org/10.1101/2020.04.02.20047050; this version posted April 3, 2020. The copyright holder for this preprint (which was not certified by peer review) is the author/funder, who has granted medRxiv a license to display the preprint in perpetuity.

All rights reserved. No reuse allowed without permission.

predictor of severe QTc prolongation in these patients. We suggest that QTc should be followed repeatedly in patients with SARS-CoV-2 infection treated with $H Y / A Z$, particularly in patients with renal failure, a common complication in patients with SARS-CoV-2.

\begin{tabular}{|c|c|}
\hline Age & $63 \pm 15$ \\
\hline Gender ( $\%$ male) & $74 \%$ \\
\hline Weight (Kg) & $86 \pm 23$ \\
\hline Coronary artery disease & $11 \%$ \\
\hline Hypertension & $65 \%$ \\
\hline Chronic kidney disease & $7 \%$ \\
\hline Diabetes mellitus & $20 \%$ \\
\hline Chronic obstructive pulmona ry disease & $8 \%$ \\
\hline Congestive heart failure & $2 \%$ \\
\hline Creatinine at initiation (mg\%) & $1.4 \pm 1.4$ \\
\hline Creatinine at max QTc (mg\%) & $1.5 \pm 1.4$ \\
\hline Acute renal failure & $6 \%$ \\
\hline Abnormal LFTs are initiation & $33 \%$ \\
\hline Abnormal LFTs at max QTc & $40 \%$ \\
\hline SSRI/SNRI, lithium, or Lacosamide & $11 \%$ \\
\hline Levofloxacin, Lopinavir/Ritonavir, or Tacrolimus & $8 \%$ \\
\hline $\begin{array}{l}\text { Norepinephrine, Phenylephrine, or } \\
\text { Vasopressin }\end{array}$ & $13 \%$ \\
\hline Amiodarone & $7 \%$ \\
\hline Baseline QTc (ms) & $435 \pm 24$ \\
\hline Maximum QTc (ms) & $463 \pm 32$ \\
\hline Day of maximum QTC & $3.6 \pm 1.6$ \\
\hline
\end{tabular}

Table 1: Baseline clincial and epidemiological characteristics $(n=84)$ 
medRxiv preprint doi: https://doi.org/10.1101/2020.04.02.20047050; this version posted April 3, 2020. The copyright holder for this preprint (which was not certified by peer review) is the author/funder, who has granted medRxiv a license to display the preprint in perpetuity. All rights reserved. No reuse allowed without permission.
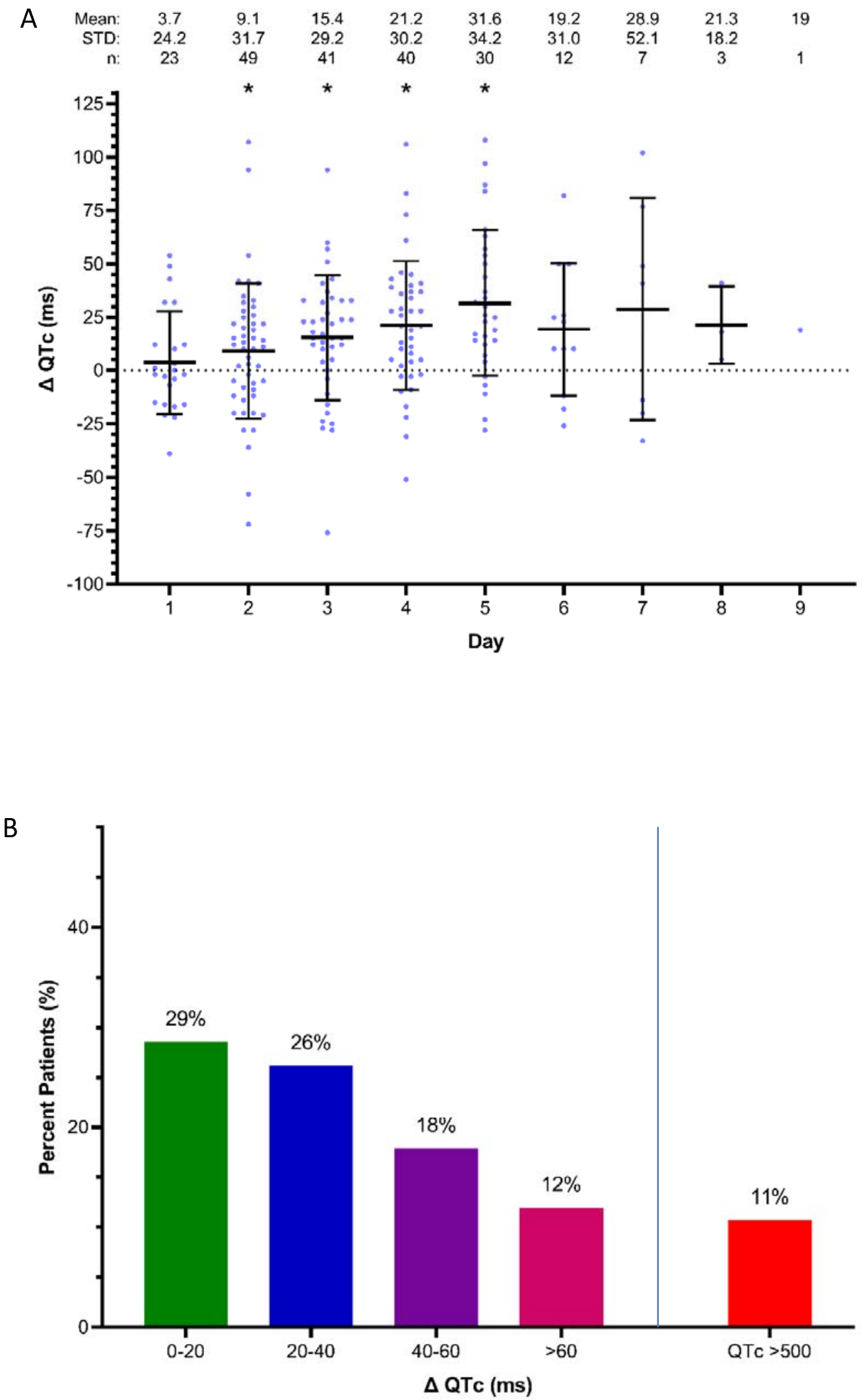
Figure 1

\begin{tabular}{|c|c|c|c|}
\hline \multicolumn{4}{|c|}{ Univariate Logistic Regressions } \\
\hline Variable & $p$ value & OR & $95 \% \mathrm{Cl}$ \\
\hline Age & 0.43 & 0.98 & 0.94-1.03 \\
\hline Gender (\% male) & 0.30 & 0.32 & $0.04-2.73$ \\
\hline Weight & 0.72 & 1.01 & $0.98-1.04$ \\
\hline $\begin{array}{c}\text { Coronary artery } \\
\text { disease }\end{array}$ & 0.25 & 2.78 & $0.48-16.03$ \\
\hline Hypertension & 0.42 & 1.97 & $0.38-10.16$ \\
\hline $\begin{array}{c}\text { Chronic kidney } \\
\text { disease }\end{array}$ & 0.09 & 5.07 & $0.78-32.79$ \\
\hline Diabetes mellitus & 0.31 & 2.18 & $0.49-9.79$ \\
\hline $\begin{array}{c}\text { Chronic } \\
\text { obstructive } \\
\text { pulmonary disease }\end{array}$ & 1 & - & - \\
\hline $\begin{array}{c}\text { Congestive heart } \\
\text { failure }\end{array}$ & 0.13 & 9.25 & $0.53-162.52$ \\
\hline $\begin{array}{c}\text { Creatinine at } \\
\text { initiation }\end{array}$ & $<0.01$ & 1.76 & $1.15-2.7$ \\
\hline $\begin{array}{c}\text { Creatinine at max } \\
\text { QTC }\end{array}$ & $<0.01$ & 1.75 & $1.2-2.54$ \\
\hline Acute renal failure & $<0.01$ & 18.25 & $2.54-131.3$ \\
\hline $\begin{array}{c}\text { Abnormal LFTs are } \\
\text { initiation }\end{array}$ & 0.29 & 0.31 & $0.04-2.75$ \\
\hline $\begin{array}{c}\text { Abnormal LFTs at } \\
\text { max QTc }\end{array}$ & 0.12 & 0.18 & $0.02-1.59$ \\
\hline $\begin{array}{l}\text { SSRI/SNRI, } \\
\text { Lithium, or } \\
\text { lacosamide }\end{array}$ & 0.97 & 1.05 & $0.12-9.49$ \\
\hline $\begin{array}{c}\text { Levofloxacin, } \\
\text { Iopinavir/ritonavir, } \\
\text { or tacrolimus }\end{array}$ & 1 & - & - \\
\hline Amiodarone & $<0.01$ & 12.00 & $1.98-72.89$ \\
\hline Baseline QTC & 0.10 & 1.03 & $1.00-1.06$ \\
\hline $\begin{array}{c}\text { Baseline QTC > } \\
460 \mathrm{~ms}\end{array}$ & 0.03 & 5.20 & $1.19-22.7$ \\
\hline \multicolumn{4}{|c|}{ Multivariate Logistic Regression } \\
\hline Variable & $p$ value & OR & $95 \% \mathrm{Cl}$ \\
\hline $\begin{array}{c}\text { Creatinine at } \\
\text { initiation }(\mathrm{mg} / \mathrm{dL})\end{array}$ & 0.07 & 1.52 & $0.97-2.37$ \\
\hline Acute renal failure & 0.01 & 19.45 & $2.06-183.38$ \\
\hline Amiodarone & 0.09 & 7.06 & $0.70-71.79$ \\
\hline $\begin{array}{c}\text { Baseline QTc > } \\
460 \mathrm{~ms}\end{array}$ & 0.28 & 2.90 & $0.42-20.24$ \\
\hline
\end{tabular}

Supplementary table 1. Predictors of maximal QTC $>500$ 


\section{Figure legend:}

Figure 1: A, the change in QTc in days post HY/AZ initiation. * $\mathrm{p}<0.01$ for QTc as compared to baseline QTC. B. percent patients with ranges of QTC prolongation.

\section{$\underline{\text { Methods }}$}

This is a retrospective study performed at NYU Langone medical center, New York. We reviewed 84 consecutive adult patients who were hospitalized at NYU Langone medical center with a positive SARS-CoV-2 disease and were treated with the combination of $\mathrm{HY} / \mathrm{AZ}$. Medical records were reviewed to obtain epidemiologic characteristics, comorbidities, baseline off-drug ECGs as well as on-drugs ECGs. The closing date of follow-up was March $28^{\text {th }} 2020$. The study was performed according to our Institutional Review Board guidance in accordance with the ethical standards laid down in the 1964 Declaration of Helsinki and its later amendments, with a waiver of informed consent. The study was approved by the IRB committee of NYU Langone Health and NYU School of Medicine.

For data collection, Microsoft Excel (MS Excel 2013, v.15.0) was used for collection of the epidemiological and clinical information.

Statistical analysis was performed using IBM SPSS Statistics 26, and figures were constructed using GraphPad Prism 8. Continuous variables are expressed as mean \pm standard deviation, and categorical variables are expressed as percentages. Normality of data samples was assessed using Shapiro-Wilk test and visual analysis 
of Q-Q plots. Hypothesis testing for comparing baseline QTc and maximum QTc was performed using paired samples $t$-test. For Figure 1 , one sample $t$-test was performed to compare each sample against a delta QTc of Oms (ie. no change from baseline). For Table 2, univariate and multivariate logistic regression was performed to identify predictors of maximum QTC $>500 \mathrm{~ms}$. For Figure 3, a receiver operating characteristics $(\mathrm{ROC})$ curve was calculated to evaluate the predictive value of baseline QTC for maximum QTC >500ms.

$\underline{\text { Data availability }}$

The data in this study will be shared upon request and approval will be designated by a data access committee. The data access committee comprises four corresponding authors and there is no restriction to data access.

\section{Contributions}

L.J and E.C contributed to the study design and data interpretation and writing of manuscript. R.B, E.S and L.W contributed to data collection analysis. M.D contributed to statistical analysis. A.A, M.S, D.H, D.P, S.B and L.C contributed to critical revision of the manuscript. All authors reviewed and approved the final version of the manuscript.

\section{$\underline{\text { References }}$}

1. World Health Organization data, 03/28/2020. 
medRxiv preprint doi: https://doi.org/10.1101/2020.04.02.20047050; this version posted April 3, 2020. The copyright holder for this preprint (which was not certified by peer review) is the author/funder, who has granted medRxiv a license to display the preprint in perpetuity.

All rights reserved. No reuse allowed without permission.

2. Gautret P, Lagier J-C, Parola P, Meddeb L, Mailhe M, Doudier B, Courjon J, Giordanengo V, Vieira VE and Dupont HT. Hydroxychloroquine and azithromycin as a treatment of COVID-19: results of an open-label non-randomized clinical trial. International Journal of Antimicrobial Agents. 2020:105949.

3. Chen C-Y, Wang F-L and Lin C-C. Chronic hydroxychloroquine use associated with QT prolongation and refractory ventricular arrhythmia. Clinical Toxicology. $2006 ; 44: 173-175$.

4. Morgan ND, Patel SV and Dvorkina O. Suspected hydroxychloroquine-associated QT-interval prolongation in a patient with systemic lupus erythematosus. JCR: Journal of Clinical Rheumatology. 2013;19:286-288.

5. HUANG BH, WU CH, HSIA CP and YIN CHEN C. Azithromycin-induced torsade de pointes. Pacing and Clinical Electrophysiology. 2007;30:1579-1582.

6. Kezerashvili A, Khattak H, Barsky A, Nazari R and Fisher JD. Azithromycin as a cause of QT-interval prolongation and torsade de pointes in the absence of other known precipitating factors. J Interv Card Electr. 2007;18:243-246.

7. Mahase E. Covid-19: six million doses of hydroxychloroquine donated to US despite lack of evidence. BMJ. 2020 Mar 23;368:m1166.

8. Zheng Y-Y, Ma Y-T, Zhang J-Y and Xie X. COVID-19 and the cardiovascular system. Nature Reviews Cardiology. 2020:1-2. 
medRxiv preprint doi: https://doi.org/10.1101/2020.04.02.20047050; this version posted April 3, 2020. The copyright holder for this preprint (which was not certified by peer review) is the author/funder, who has granted medRxiv a license to display the preprint in perpetuity.

All rights reserved. No reuse allowed without permission.

9. Wang $M$, Cao R, Zhang L, et al. Remdesivir and chloroquine effectively inhibit the recently emerged novel coronavirus (2019-nCoV) in vitro. Cell Res. 2020;30:269-271.

10. Yao $\mathrm{X}$, Ye $\mathrm{F}$, Zhang $\mathrm{M}$, et al. In vitro antiviral activity and projection of optimized dosing design of hydroxychloroquine for the treatment of severe acute respiratory syndrome coronavirus 2 (SARS-CoV-2). Clin Infect Dis. 2020.

11. Gautret P, Lagier JC, Parola $\mathrm{P}$, et al. Hydroxychloroquine and Azithromycin as a treatment of COVID-19: preliminary results of an open-label non-randomized clinical trial. medRxiv. 2020:2020.2003.2016.20037135.

12. Erin K. McCreary, PharmD, BCPS, BCIDP1,\# and Jason M. Pogue. COVID-19 Treatment: A Review of Early and Emerging Options. Open Forum Infectious Diseases. Accepted manuscript

13. Goldenberg I, Moss AJ, Peterson DR, et al. Risk factors for aborted cardiac arrest and sudden cardiac death in children with the congenital long-QT syndrome.

Circulation. 2008;117:2184-2191.

14. Hobbs JB, Peterson DR, Moss AJ, et al. Risk of aborted cardiac arrest or sudden cardiac death during adolescence in the long-QT syndrome. JAMA. 2006;296:12491254.

15. Sauer AJ, Moss AJ, McNitt S, et al. Long QT syndrome in adults. J Am Coll Cardiol. 2007;49:329-337.

16. Giudicessi JR, Noseworthy PA, Friedman PA, Ackerman MJ. Mayo Clinic Proceedings March 25, 2020, online ahead of print. 
medRxiv preprint doi: https://doi.org/10.1101/2020.04.02.20047050; this version posted April 3, 2020. The copyright holder for this preprint (which was not certified by peer review) is the author/funder, who has granted medRxiv a license to display the preprint in perpetuity.

All rights reserved. No reuse allowed without permission. 